This investigation was supported by grant $H E 03755$ from the National Institutes of Health, U.S. Public Health Service.

RICHaRd L. Glasser

JoE W. TIPPETT

Vartan A. Davidian, Jun.

Department of Physiology,

University of North Carolina School of Medicine, Chapel Hill.

'Wang, S. C., and Ngai, S. H., in Handbook of Physiology, Respiration, edit. by Fenn, W. O., and Rahn, H., 1, 487 (Williams and Wilkins, Baltimore, 1964).

${ }^{2}$ Hoff, H. E., and Breckenridge, C. G., Amer. J. Physiol., 158, 157 (1949).

${ }^{3}$ Breckenridge, C. G., and Hoff, H. E., Amer. J. Physiol., 160, 385 (1950).

‘Wang, S. C., Ngai, S. H., and Frumin, M. J., Amer. J. Physiol., 190, 333 (1957).

6 Pollock, L. J., and Davis, L. E., Arch. Neurol. Psychiat., 10, 391 (1823).

- Glasser, R. L., Perez-Reyes, M., and Tippett, J. W., Amer. J. Physiol., 207, 1133 (1964)

" Glasser, R. L., Amer. J. Physiol., 198, 421 (1960).

- Glasser, R. L., Amer. J. Physiol., 203, 449 (1962).

- Stella, G., J. Physiol., 96, 26 P (1939).

${ }^{10}$ Moruzzi, G., J. Neurophysiol., 3, 20 (1940).

"Zanchetti, A., and Zoccolini, A., J. Neurophysiol., 17, 475 (1954).

${ }^{12}$ Stella, G., and Stevan, G., Arch. Intern. Pharmacodyn., 136, 1 (1962).

\section{Heat Stress Degranulation of the Basophil Leucocyte in Man}

LoNG an obscure but distinctive type of leucocyte, the basophil has in recent years been shown to play an active part in the immediate-type hypersensitivity reac-

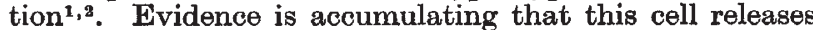
its granules containing histamine and heparin in the presence of an antigen and a reactive antibody. These morphological changes of degranulation, however, are not specific nor limited to the allergic state. Certain drugs may induce similar degranulation in the complete absence of any sensitivity ${ }^{3}$. The investigation reported here extends our view of the role of this cell, since it shows that, in man, acute heat stress also induces the morphological changes of degranulation in the circulating basophil.

Ten normal, healthy, White and Negro male adults served as subjects. All medication was interdicted for 2 weeks before and during the entire investigation. Heat stress was achieved by exposing the men to an environment of $120^{\circ} \mathrm{F}$ with 50 per cent relative humidity for 30 min periods. To assess possible acclimatization, the 30 . min stress was repeated daily for 7 days. Heparinized venous blood samples were obtained for absolute and morphological basophil counts ${ }^{2}$ immediately before, immediately after, as well as 1 and $4 \mathrm{~h}$ after each daily heat stress. Control counts and morphological assessments were undertaken before and 1 week after the last heat stress. Cells were classified as normal or degranulated, that is, having fewer than normal granules, showing cytological evidence of extrusion of granules, or showing less staining. Table 1 summarizes representative data showing that, although the basophil count remained essentially normal, the subjects experienced a significant change in the morphology of the cell immediately after 30 min of heat stress. This was evident at $2 \mathrm{~h}$, as well as at $4 \mathrm{~h}$, and to a lesser degree at $24 \mathrm{~h}$.

In nine of the ten subjects, $30 \mathrm{~min}$ of high temperature produced a dramatic increase in the number of basophils showing degranulation. The effect persisted for the entire 7 days, acclimatization not being evident. However, after a week of no exposure in the thermal chamber, the number of degranulated basophils returned to, or below, normal in each of the men.

The mechanism and significance of this heat-induced change in the basophil remain unknown, but it is interesting to speculate that perhaps the basophil releases the vasodilator histamine in response to elevated temperatures. This could thus serve as an adaptive mechanism since body temperatures did not rise appreciably during the $30 \mathrm{~min}$ of stress. It should be noted that the basophil is thermo-sensitive in vitro, remaining normal in chilled blood for longer than in blood kept at $37^{\circ} \mathrm{C}$. Further investigation of the factors accounting for this stressinduced degranulation of the basophil would seem to be indicated.

This investigation was supported by Public Health Service research grant $H E$ 07428-03 from the Division of Research Grants, National Institutes of Health.

\section{SorRel S. Resnik \\ WALTER B. SHELLEY}

Department of Dermatology,

University of Pennsylvania School of Medicine, Philadelphia.

1 Shelley, W. B., and Parnes, H. M., J. Amer. Med. As8oc., 192, 368 (1965).

2 Juhlin, L., and Westphal, O., Acta Dermato-Venereol., 42, 273 (1962).

- Shelley, W. B., and Resnik, S. S., J. Invest. Derm., 43, 491 (1964).

\section{Cholinesterase in the Mammalian Kidney}

CHolinesterase activity has been demonstrated in portions of the renal tubule ${ }^{1,2}$, but no one has determined which segment of the nephron contains the enzyme. This is surprising as cholinesterase activity is known to be associated with sodium transport in a number of tissues and might therefore be associated with sodium transport in the kidney. Koch ${ }^{8}$ showed that cholinesterase is important for sodium transport through the gill epithelium of the freshwater crab and for sodium absorption from the anal papillae of the insect larva Chironomus plumosus. The gills of fish transport sodium and contain cholinesterase ${ }^{4}$. In frog skin Koblick et al. ${ }^{5}$ found an excellent correlation of cholinesterase activity with average short circuit current and thus with sodium transport. Kamento ${ }^{6}$ found cholin-

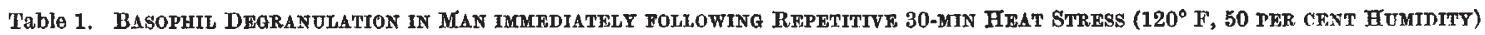

\begin{tabular}{|c|c|c|c|c|c|c|c|c|c|c|}
\hline \multirow{2}{*}{$\begin{array}{c}\text { Subject } \\
\text { No. }\end{array}$} & & \multirow{2}{*}{$\begin{array}{c}\text { Day 0 } \\
\text { (before } \\
\text { heat stress) }\end{array}$} & \multicolumn{7}{|c|}{ Days } & \multirow{2}{*}{$\begin{array}{l}\text { Day } 14 \text { (no } \\
\text { heat stress } \\
\text { for } 1 \text { week) }\end{array}$} \\
\hline & & & 1 & 2 & 3 & 4 & 5 & 6 & 7 & \\
\hline $\begin{array}{r}2 \\
3 \\
4 \\
5 \\
6 \\
7 \\
8 \\
9 \\
10\end{array}$ & $\begin{array}{l}\text { Absolute basophil } \\
\text { count (ABC) } \\
\text { Degranulation (\%) } \\
\text { ABC } \\
\text { Degranulation (\%) } \\
\text { ABC } \\
\text { Degranulation (\%) } \\
\text { ABC } \\
\text { Degranulation (\%) } \\
\text { ABC } \\
\text { Degranulation (\%) } \\
\text { ABC } \\
\text { Degranulation (\%) } \\
\text { ABC } \\
\text { Degranulation (\%) } \\
\text { ABC } \\
\text { Degranulation (\%) } \\
\text { ABC } \\
\text { Degranulation (\%) } \\
\text { ABC } \\
\text { Degranulation (\%) }\end{array}$ & $\begin{array}{l}69 \\
13 \\
36 \\
25 \\
25 \\
32 \\
33 \\
39 \\
15 \\
26 \\
66 \\
21 \\
34 \\
88 \\
71 \\
29 \\
49 \\
81 \\
30 \\
13\end{array}$ & $\begin{array}{l}49 \\
79 \\
39 \\
51 \\
43 \\
79 \\
34 \\
76 \\
38 \\
41 \\
78 \\
29 \\
36 \\
52 \\
45 \\
88 \\
56 \\
14 \\
41 \\
82\end{array}$ & $\begin{array}{l}59 \\
42 \\
20 \\
20 \\
34 \\
76 \\
35 \\
45 \\
21 \\
66 \\
65 \\
24 \\
45 \\
51 \\
33 \\
84 \\
48 \\
27 \\
41 \\
82\end{array}$ & $\begin{array}{l}46 \\
80 \\
28 \\
32 \\
35 \\
65 \\
43 \\
69 \\
19 \\
73 \\
66 \\
57 \\
41 \\
24 \\
36 \\
86 \\
40 \\
75 \\
40 \\
82\end{array}$ & $\begin{array}{l}41 \\
85 \\
39 \\
27 \\
46 \\
67 \\
33 \\
54 \\
28 \\
71 \\
75 \\
35 \\
31 \\
42 \\
38 \\
81 \\
26 \\
92 \\
39 \\
79\end{array}$ & $\begin{array}{l}53 \\
81 \\
41 \\
39 \\
55 \\
74 \\
44 \\
63 \\
23 \\
69 \\
86 \\
51 \\
35 \\
45 \\
51 \\
76 \\
54 \\
94 \\
84 \\
88\end{array}$ & $\begin{array}{l}49 \\
59 \\
24 \\
54 \\
55 \\
61 \\
26 \\
76 \\
15 \\
86 \\
80 \\
56 \\
25 \\
32 \\
39 \\
84 \\
34 \\
44 \\
21 \\
76\end{array}$ & $\begin{array}{l}71 \\
42 \\
25 \\
64 \\
55 \\
65 \\
34 \\
85 \\
20 \\
75 \\
70 \\
87 \\
28 \\
30 \\
45 \\
75 \\
54 \\
75 \\
21 \\
76\end{array}$ & $\begin{array}{r}65 \\
5 \\
35 \\
14 \\
60 \\
18 \\
63 \\
10 \\
50 \\
12 \\
45 \\
22 \\
46 \\
30 \\
73 \\
27 \\
54 \\
27 \\
46 \\
19\end{array}$ \\
\hline
\end{tabular}

